\title{
Katarzyna Konik
}

Uniwersytet Jagielloński

\section{Wizja państwa Ayn Rand - urzeczywistnienie kapitalizmu}

(Ayn Rand's vision of the state - realization of capitalism)

\begin{abstract}
The purpose is to define Ayn Rand's vision of state as form of capitalism. To gain this aim, necessarry is to show her conception of individual and human rights. Definition of man is depended on human goals: survival, happiness and vested interest. They should be creating by the ethics. Cause the ethics affords human tree fundamental virtues: rationality, effectiveness and pride, wchich show people how to live in the right way. The human rights belong only to individual and its conception belongs to sphere between politics and morality. The most important rights are right to live and property right, guaranteed by the state. The state has three main function: respect human rights and freedoms, right to coercion and judiciary. These elements are basis of capitalism in the liberal state. Cause capitalism is the political, social and economic system which should be argued by the ethics.
\end{abstract}

\section{Keywords}

Ayn Rand, capitalism, human rights, state, ethics

\section{Słowa kluczowe}

Ayn Rand, kapitalizm, prawa człowieka, państwo, etyka

\section{Wstęp}

Koncepcja państwa w obrębie nurtu myśli libertariańskiej przybiera wiele form. Łatwo zauważalne jest, że każdy z myślicieli wpisywany w tę doktrynę, prezentuje własną wizję systemu instytucjonalnego - od całkowitej rezygnacji z niej, po państwo minimum ${ }^{1}$. Kontrowersyjne oceny najczęściej spotykane są w przypadku postulatu pełnego anarchizmu. Wiąże się to oczywiście z trwającymi i ciągle rodzącymi się sporami w tej sferze.

\footnotetext{
${ }^{1}$ Przykłady stanowić może ruch anarchistyczny w obrębie libertarianizmu reprezentowany przez Wandę MacElroy, Carla Watnera oraz Samuela Edwarda Konkina, czy też ruch minarchistyczny reprezentowany przez Roberta Nozicka.
} 
W nurt libertariański wpisywana jest amerykańska myślicielka Ayn Rand. Chociaż sama za swego życia zaprzeczała przynależności do libertarianizmu, jej wkład w tę doktrynę pozostaje istotny ${ }^{2}$. Co za tym idzie, przedstawiana przez nią wizja państwa staje się tematem godnym rozważań. Nie można pominąć faktu, że poglądy autorki Hymnu należy uznać za filozofię obiektywistyczną, gdyż to założenie i skonstruowanie pojęcia obiektywizmu stanowi podstawową przesłankę do wniosków Rand w sferze politycznej i etycznej.

Jej twórczość nieoceniona w Stanach Zjednoczonych, na polskiej płaszczyźnie naukowej nie jest szczególnie spopularyzowana ${ }^{3}$. Dylematy, które podejmowała w swoich rozważaniach (lata 60.-70. XX wieku) do dziś pozostają aktualne ${ }^{4}$.

Jednakże to, co w przypadku niniejszych rozważań pozostaje kluczowe, to Randowskie oparcie koncepcji państwa na fundamencie wolnego społeczeństwa oraz zasadzie kapitalizmu ${ }^{5}$ Te dwa elementy zostają ze sobą połączone - Rand zwraca uwagę, że wolne społeczeństwo należy rozumieć jako szeroko pojmowany kapitalizm, a jego warunek winna stanowić realizacja zasad praw jednostki.

Dla jasności rozważań i logicznego wywodu, tekst podzielony został na cztery części. Mimo, że główny temat stanowi koncepcja państwa, konieczne jest pochylenie się nad rozumieniem człowieka w obiektywizmie. Postrzeganie państwa uwarukowane jest bowiem sposobem zapatrywania się na jednostkę. Stąd pierwsza część skupi się na pojmowaniu przez Rand jednostki. Kolejna pozwoli na przedstawienie praw jednostki wynikających z samego faktu istnienia. Następnie ukazana zostanie wizja państwa i rządu. Ostatnia

\footnotetext{
${ }^{2} \mathrm{~W}$ historii idei nie jest rzadkością fakt, że myśliciel czy myślicielka separuje się od danego nurtu, a swoimi koncepcjami przyczynia się do jego rozwoju.

${ }^{3}$ Dorobek polski w zakresie koncepcji Rand nie jest zbyt szeroki. Bezpośrednio o Rand pisał Ryszard Legutko w rozdziale Leseferyzm racjonalistyczny. Ludwig von Mises i libertarianie w książce Spory o kapitalizm. Kolejne pozycje, odnoszące się do dorobku Ayn Rand to fragmenty z książek: Dariusza Jurusia W poszukiwaniu podstaw libertarianizmu: w perspektywie Rothbardowskiej koncepcji własności, Justyny Miklaszewskiej Libertariańskie koncepcje wolności i własności, Małgorzaty Modrzejewskiej Libertariańskie koncepcje jednostki i państwa we współczesnej amerykańskiej myśli politycznej, Doroty Sepczyńskiej Libertarianizm: mało znane dzieje pojęcia zakończone próbą definicji, Tomasza Teluk, Koncepcje państwa we wspótczesnym libertarianizmie oraz w pracach zbiorowych Libertarianizm: teoria, praktyka, interpretacje (red. W. Bulira, W. Gogłoza), Oblicza anarchizmu i libertarianizmu w filozofi i polityce (red. J. Michalczenia, A. Sobiela), Oblicza wolności: od klasycznego liberalizmu do libertarianizmu (red. T. Słupik, S. Górka, G. Szewczyk). Ponadto spotkać można definicje słownikowe, z których najpełniejszą sanowi opracowanie Jacka Bartyzela w Encyklopedii Białych Plam, pod redakcją Artura Winiarczyka (tom XV, Radom 2005).

4 Zwłaszcza koncepcja etyki oraz rozważania dotyczące problemów ówczesnego świata, ze szczególnym uwzględnieniem multikulturalizmu i enviromentalizmu.

${ }^{5}$ A. Rand, Korzenie wojny, w: eadem, Kapitalizm. Nieznany ideał, tłum. J. Łoziński, Poznań 2013, s. 58. Także: A. Rand, Prawa człowieka, w: eadem, Kapitalizm. Nieznany..., op. cit., s. 521.
} 
część skupi się na mechanizmie kapitalizmu, formułowanego jako system gwarantujący sprawne funkcjonowanie we wszystkich sferach społecznych.

\section{Randowska jednostka}

Autorka Źródła wychodzi z założenia, że każda koncepcja dotycząca sfery społecznej należy poprzedzić rozważaniami na temat założeń co do jednostki ${ }^{6}$. Studiując bowiem człowieka poznajemy właściwości rządzące społeczeństwem. Zabieg odwrotny nie daje nam powiem żadnej wiedzy - analiza społeczeństwa nie pozwoli nam na wnioskowanie o jednostkach ${ }^{7}$.

Fundamentalnym spostrzeżeniem jest fakt, że człowiek uznawany jest za istotę, rodzącą się jako tabula rasa ${ }^{8}$. Nie posiada automatycznego systemu przetrwania, czyli zbioru wartości i zasad, których powinien przestrzegać i zgodnie z którymi powinien postępować, aby podtrzymywać i w pełni wykorzystywać życie. Obdarzony jest natomiast dwoma mechanizmami - mechanizmem poznania oraz mechanizmem emocjonalnym ${ }^{9}$. Z działania tych dwóch mechanizmów Rand wywodziła, że człowiek jest jednostką samodzielną, szanującą się i działającą zgodnie z własnym interesem racjonalnym, a jego sfera emocjonalna pozostaje poskromiona przez poznanie.

Celem jednostki jest osiągnięcie szczęścia, która interpretowane jest jako stan świadomości, wynikający z osiągnięcia własnych wartości, czyli postępowanie zgodnie z cnotą egoizmu. Z niej zaś wynika godność człowieka. Egoizm w myśli Rand jest terminem podlegającym rehabilitacji. Zdaniem autorki Powrotu człowieka pierwotnego, egoizm należy do kategorii pojęć, które zostały wypaczone i przywłaszczone przez religię ${ }^{10}$. Konieczne jest sprowadzenie go wyłącznie do sfery języka, pozostającej poza działaniem człowieka, niemogącej się urzeczywistnić. Samo doświadczenie egoizmu pozostaje doświadczeniem szlachetnym. W obiektywistycznej koncepcji myślicielki oznacza bowiem troskę o własny interes. Nie zawiera treści merytorycznej - nie określa interesu, lecz jest samą powinnością, bez jej precyzowania ${ }^{11}$. Zdaniem Rand, egoizm pozostawał definiowa-

\footnotetext{
${ }^{6}$ A. Rand, Wprowadzenie, w: eadem, Kapitalizm. Nieznany..., op. cit., ss. 19-20.

7 Jest to założenie typowe dla nauk społecznych. Cf. B. Krauz-Mozer, W. Szostak, Teorie polityki: założenia metodologiczne, Warszawa 2005.

${ }^{8}$ A. Rand, Etyka absolutna, w: eadem, Cnota egoizmu, tłum. na podst. wyd. Oficyny Liberałów (Warszawa 1987), Poznań 2000, ss. 19-20, 30. Także: A. Rand, Etyka sytuacji krytycznych, w: eadem, Cnota egoizmu..., op. cit., s. 55.

9 A. Rand, Etyka absolutna..., op. cit., s. 31.

${ }^{10}$ Cf., A. Rand, Wstęp, w: eadem, Cnota egoizmu..., op. cit.

${ }^{11}$ Ibidem.
} 
ny niewłaściwie i był wpisywany w kategorie dobra i zła jako sama idea. Stanowi on jednak prawo i obowiązek realizacji interesu własnego. Dopiero sprecyzowanie tego, co uznaje się za własny interes pozwala na ocenę jego właściwości i określenie go jako dobrego lub złego.

Odpowiedzialność za wyznaczanie interesu spoczywa na etyce, gdyż kreując pożądane postawy moralne generuje ustanawianie przez ludzi korzystnych i niekrzywdzących interesów. W związku z tym obiektywizm postuluje racjonalny egoizm, czyli realizację rozsądnego własnego interesu. Ten postulat winien stanowić wzór wartości odniesiony jako postawa do tłumaczenia rzeczywistości w sferze moralnej, społecznej, ekonomicznej i prawnej.

Ponadto nadrzędnym celem jednostki pozostaje wspomniane już przetrwanie i życie, składające się z dwóch aspektów - fizycznego i etycznego. Jednostka jest bowiem postrzegana jako całość, system spójny - nie działa w trybie cykli biologicznych, lecz jej życie jest pełnym urzeczywistnieniem kwintesencji człowieczeństwa ${ }^{12}$. W związku z tym egzystencja, aby była w pełni urzeczywistniona, musi realizować zarówno potrzeby fizyczne i powinności etyczne. Aby pozostawać człowiekiem, należy zadbać o pełną samorealizację w tych dwóch sferach. Należy zatem podjąć środki, wykorzystywać metody, spełniać warunki i osiągać cele konieczne do przetrwania racjonalnej istoty ludzkiej ${ }^{13}$. Służyć ma temu prawo do formułowania niezależnych sądów, opartych na doświadczeniu zmysłowym.

W wywodzie należy dodać, że za nadrzędną kategorią, jaką jest egoizm, w obiektywizmie zawarte są trzy cnoty: racjonalności, skuteczności oraz dumy ${ }^{14}$. Pozwalają one w pełni zobrazować jak Rand postrzega człowieka.

Cnota racjonalności odnosi się do wartości jaką jest rozum. Stanowi on bowiem źródło skutecznej pracy i innych cnót. Ponadto gwarantuje pełną świadomość i pozostaje jedynym źródłem wiedzy oraz kryterium oceniania i osądzania pozostałych wartości. Odnosi się do postrzeganej rzeczywistości w oparciu o analizowanie relacji przyczyna - skutek - odpowiedzialność. Na podstawie spostrzeżeń rozumowych podejmowane są decyzje. Są to jednak decyzje oparte o wnioski wyciągnięte z określonego kontekstu sytuacyjnego, z określonego doświadczenia zmysłowego. Nie mogą one przybierać formy pozaempirycznej. Cnota racjonalności wymusza i gwarantuje postępowanie według kolejnych cnót. Są nimi integralność, opierająca się na braku poświęcenia i niepodporządkowywaniu się in-

12 A. Rand, Etyka absolutna..., op. cit., ss. 17-18.

13 A. Rand, Czym jest kapitalizm, w: eadem, Kapitalizm. Nieznany..., op. cit., s. 13, 22. Także: A. Rand, O naturze rządu, w: eadem, Kapitalizm. Nieznany..., op. cit., s. 535. Także: A. Rand, Etyka absolutna..., op. cit., s 26.

14 A. Rand, Etyka absolutna..., op. cit., s. 27. 
nym, uczciwość względem własnych zmysłów, polegająca na zaufaniu względem tego, co postrzega jednostka, oraz sprawiedliwość, stanowiąca środek do właściwej oceny ${ }^{15}$.

Drugą istotną wartością jest cel i związana z nim cnota skuteczności. Związanie celu i skuteczności pozwala na określanie innych wartości i ich hierarchizowanie. Dodatkowo stanowi gwarant wydajnej pracy poprzez podtrzymywanie ciągłej aktywności ludzkiego umysłu i jego najpełniejsze wykorzystanie. Skuteczność ma służyć dostosowywaniu świata do ludzkich potrzeb i pracy produkcyjnej. Człowiek bowiem jest istotą wyposażoną w siły twórcze, które winien cały czas wykorzystywać, nie pozostając jedynie naśladowcą osiągnięć innych ludzi - wiedzy i umiejętności. Ponadto motywem pracy człowieka powinny pozostawać własne potrzeby i pragnienie oraz zysk osobisty.

Ostatnią, wymienioną wprost w rozważaniach autorki Kapitalizmu. Nieznanego ideału wartością, jest ambicja i przypisana jej cnota dumy. Jest to ambicja moralna, odnosząca się do osiąganych przez człowieka rezultatów. Ma na celu dążenie do perfekcji moralnej i zakorzenienie w jednostce idei, że jej postępowanie ma być postępowaniem zgodnym z wypracowanym wzorem. Istotna jest tu rola godności ludzkiej, poprzez którą gwarantowana jest i realizowana cnota dumy. Duma intelektualna nie oznacza jednak wszechwiedzy - człowiek z zasady jest omylny ${ }^{16}$.

Te trzy wartości instrumentalne i odpowiadające im cnoty, są podporządkowane celowi nadrzędnemu i ostatecznemu. Jest nim wyznaczony przez żywą jednostkę wzór własnego życia. Nie stanowi on tylko podtrzymywania ciągłości biologicznych funkcji życiowych, ale również dążenie do prawdy, wiedzy i samodoskonalenia się w sferze etycz$n j^{17}$.

\section{Prawa jednostki}

Autorka Cnoty egoizmu, zauważa, że prawo to pojęcie z zakresu moralności, które odnosi się to tworzenia i ochrony jednostkowej moralności w sferze społecznej ${ }^{18}$. Przysługuje ono jedynie człowiekowi i określa wolność działań jednostki w kontekście społecznym. Przynależność prawa do człowieka w sposób istotny przekłada się na inne poglądy i spostrzeżenia Rand ${ }^{19}$. Prawo pełni rolę pomostu pomiędzy etyką a polityką. Stanowi na-

\footnotetext{
15 Ibidem, s. 28.

16 A. Rand, Czym jest..., op. cit., s. 12.

17 Cf., A. Rand, Etyka absotluna..., op. cit.

18 A. Rand, Czym jest..., op. cit., ss. 24., 521, 524.

${ }^{19}$ Przykład może stanowić w tym aspekcie argumentacja bezzasadności uprzywilejowywania grup społecznych, zwłaszcza w przypadku mniejszości rasowych.
} 
rzędzie podporządkowywania państwa prawu moralnemu, które odgrywa kluczową rolę w funkcjonowaniu społeczeństwa. Co za tym idzie - prawo jest to narzędzie ograniczenia władzy państwowej ${ }^{20}$. Amerykańska filozofka wielokrotnie podkreśla, że prawa nie przysługują grupom. Przekłada się to na koncepcję państwa w taki sposób, że przekreśla możliwość istnienia w ramach instytucji rozwiązań socjalnych. Zwłaszcza takich, które uprawniają tylko i wyłącznie konkretną zbiorowość, pozostając tym samym niezgodnymi $\mathrm{z}$ racjonalną organizacją państwa.

Podstawowym prawem jest prawo człowieka do życia, czyli wolności od fizycznego przymusu, przemocy i ingerencji ze strony innych ${ }^{21}$. Dla jednostki ma zatem wydźwięk w pełni pozytywny - gwarantuje działanie wedle własnej oceny, dla własnego celu oraz na mocy dobrowolnego wyboru. Prawo do życia stanowi źródło innych praw. Są one możliwe do urzeczywistnienia dzięki realizacji kolejnego prawa o szczególnej randze w koncepcji Rand - prawa własności. Wynika z tego, że bez niego - bez prawa własności - żadne inne uprawnienie nie może zostać zrealizowane.

Definicja prawa własności nie ogranicza się do samego posiadania. Jest ono pomyślane przede wszystkim jako prawo do działania ${ }^{22}$. Nie wiąże się z samym dysponowaniem konkretną rzeczą, obiektem, lecz stanowi pole do wykorzystywania możliwości, realizacji celów i osiągania zamierzeń. Co więcej, należy dodać, że instytucja ta w pełni powstała i rozpoczęła funkcjonowanie właśnie poprzez rozwój kapitalizmu²3.

\section{Państwo}

W rozważaniach państwa konieczne jest zwrócenie uwagi na rolę rządu, który stanowi urzeczywistnienie kompetencji państwowych. Zdaniem Rand, istotne pozostają trzy kwestie związane z jego działalnością.

Przede wszystkim u źródeł władzy rządu leży zgoda rządzonych. Innymi słowy to pojęcie prawa i jego akceptacja daje możliwość konstruowania wolnego społeczeństwa. Rząd stanowi instytucję, której jako jedynej przysługuje wyłączne prawo wymuszania określonych reguł społecznych na określonym terenie ${ }^{24}$. Zakładając jednak, że to właśnie ludzki

\footnotetext{
${ }^{20}$ Cf., A. Rand, Prawa człowieka..., op. cit.

${ }^{21}$ Cf., A. Rand, Etyka absotluna..., op. cit. Także: Cf., A. Rand, Kapitalizm. Nieznany..., op. cit.

22 A. Rand, Prawa człowieka..., op. cit., s. 525.

23 A. Rand, Czym jest..., op. cit., s. 16.

${ }^{24}$ Ibidem, s. 24-25. Także: A. Rand, O naturze..., op. cit., s. 535.
} 
umysł jest narzędziem ludzkiego przetrwania i środkiem do zdobywania wiedzy, warunek konieczny jaki musi spełniać rząd, to przyzwolenie na wolność myślenia i wolność wyboru zgodnego z własnym osądem. Istnienie społeczeństwa poddanego pewnym normom jest konieczne, gdyż generuje najbardziej sprzyjające okoliczności dla życia jednostki. Otoczenie społeczne pozwala bowiem na rozwój, zdobywanie wiedzy oraz wymianę. To społeczeństwo daje możliwość urzeczywistnienia sprawności i efektywności w większym stopniu, niż w przypadku samotnej egzystencji jednostki.

Druga ważny aspekt $\mathrm{w}$ przypadku rozważania rządu, to pojęcie siły fizycznej. Państwo jako instytucja, czyli rząd, posiadając monopol na użycie fizycznej siły, winno skupić się na działalności kontrolującej użycie owej siły ${ }^{25}$. W relacjach społecznych ma dążyć do jej całkowitego wykluczenia, gdyż w racjonalnym społeczeństwie narzędziami walki winna zostawać perswazja, dyskusja i argumenty merytoryczne. Działania te muszą być określone w sposób precyzyjny, w odpowiednim stopniu ograniczone, dokładnie opisane oraz podlegać kontroli. Kontrola stanowi przypadek, w którym jednostce przysługuje wolność podejmowania działań, a osobowa reprezentacja państwa jest poddana sprawdzeniu przez normy ustawowe. Należy tu także dodać, że ustawy wywodzone są z natury i celu rzetelnego rządu. Mają one na celu ochronę podstawowych praw jednostek ${ }^{26}$.

Zasadę stanowi także, że państwo nie powinno poszerzać swej działalności. Winno natomiast ograniczać w sposób maksymalny przymus, który mu przysługuje (tylko w uzasadnionych przypadkach) i nie tworzyć konfliktów pomiędzy prawem a naturą ludzką. Jego rolą jest uznawanie praw jednostki, a co się z tym wiąże musi akceptować warunki godziwego przetrwania.

Jednakże podsumowując: w przypadku używaniu przymusu dozwolona jest działalność policji, chroniąca przed fizyczną agresją ze strony innych jednostek oraz sił zbrojnych, chroniąca przed agresją fizyczną ze strony innych państw lub czynników zewnętrznych.

Trzecim elementem, stanowiącym definicję państwa jest kwestia władzy sądowniczej. Państwo posiada istotną funkcję - arbitra, rozstrzygającego spory pomiędzy jednostkami, zawierającymi umowę ${ }^{27}$. Jest to gwarant funkcjonowania pokojowego społeczeństwa

\footnotetext{
25 A. Rand, Amerykańska prześladowana mniejszość: wielki biznes, w: eadem, Kapitalizm. Nieznany..., op. cit., s. 72. Także: A. Rand, O naturze..., op. cit., s. 539.

26 A. Rand, Amerykańska prześladowana..., op. cit., s. 73. Także: A. Rand, O naturze..., op. cit., s. 540.

27 A. Rand, O naturze..., op. cit., s. 541.
} 
i wiąże się z ustanowieniem władzy sądowniczej. Im bardziej złożona jest cywilizacja, im bardziej skomplikowane umowy zostają w sposób wolny zawierane pomiędzy jednostkami, tym większa jest potrzeba zabezpieczenia interesów jednostek w tym wymiarze. Co ważne, Rand nie zwraca uwagi na istotność władzy sądowniczej w przypadku łamania prawa do życia, etc., lecz wywodzi władzę sądowniczą z konieczności rozwiązywania sporów, wynikających z umów.

Tak widziana rola rządu uzmysławia, że Rand nie dostrzega możliwości istnienia anarchii, gdyż w jej przypadku nie istnieją środki ochrony i kontroli. Autorka We the Living uznaje za konieczne istnienie systemu państwowego.

\section{Kapitalizm}

Rozważając kapitalizm Randowski, nie można nie zwrócić uwagi na stwierdzenie o dotychczasowym braku filozofii, uzasadniającej kapitalizm. Myślicielka uważa, że kapitalizm w swej czystej postaci nie został w pełni nigdy urzeczywistniony ${ }^{28}$. Najbliżej ideału znajdowały się Stany Zjednoczone po II wojnie światowej. Jednakże zimna wojna doprowadziła do promowania socjalizmu, etatyzmu i trudności w obronie kapitalizmu ${ }^{29}$.

Próby zachowania kapitalizmu podejmowali zdaniem myślicielki liberałowie oraz konserwatyści ${ }^{30}$. Jednakże w obydwu przypadkach rozważania i argumentacja merytoryczna obierała niewłaściwy kierunek, nie pozwalając tym samym na skuteczną obronę ideału państwa kapitalistycznego.

W przypadku liberałów obrona ta nie była skuteczna, gdyż promując kapitalizm, promowali także etatyzm, wpływający na zwiększenie ingerencji państwa. Ponadto hasła kapitalistyczne starano się przekazać w taki sposób, by usunąć z nich sam termin kapitalizm, uznając jego pejoratywny wydźwięk. Skutkiem tego było pójście w kierunku, a następnie realizowanie gospodarki mieszanej, która próbując urzeczywistnić sprzeczne

\footnotetext{
28 A. Rand, Czym jest..., op. cit., s. ss. 46-47.

29 Etatyzm szeroki i w sposób pełny jest zdefiniowany przez Rand w artykule Korzenie wojny. Cf., A. Rand, Korzenie wojny..., op. cit., ss. 53-69. W największym skrócie myślowym, zdaniem Rand, kapitalizm utożsamiać należy z wolnością ekonomiczną, etatyzm zaś z państwową kontrolą. A. Rand, Nowy faszyzm: władza mocą konsensusu, w: eadem, Kapitalizm. Nieznany..., op. cit., s. 343.

30 A. Rand, „Ekstremizm” czyli sztuka oczerniania, w: eadem, Kapitalizm. Nieznany..., op. cit., ss. 287-288; A. Rand, Konserwatyzm: nekrolog, w: eadem, Kapitalizm. Nieznany..., op. cit., ss. 312-316; A. Rand, Nowy faszyzm..., op. cit., s. ss. 338-339; A. Rand, Gruzy konsensusu, w: eadem, Kapitalizm. Nieznany..., op. cit., s. 367. Dodatkowo należy zauważyć, że Rand posługując się pojęciami „liberałowie” oraz „konserwatyści” stosuję niniejszy zapis, tj. z użyciem cudzysłowu.
} 
ze sobą ideały, nie mogła stanowić skutecznego systemu funkcjonowania państwa. Rand krytykuje także zjawisko konsumeryzmu, które jej zdaniem wyniknęło z dotychczasowych działań $^{31}$. Konsumeryzm pozwala bowiem na przeniesienie siły działania z przedsiębiorcy, czy wytwórcy na konsumenta, od którego tym samym uzależnia się pomyślność rynku i gospodarki. Obiektywizm zakłada w swych czołowych ideach konieczność związania produkcji i wytwórczości z jednostką sprawczą, nie zaś z niej korzystającą.

Obrona konserwatystów w stosunku do kapitalizmu ma swoje źródło w posługiwaniu się trzema argumentami wynoszonymi z wiary, tradycji i ludzkiej ułomności.

Pierwszy z nich zakłada uzasadnienie kapitalizmu jako właściwego ideału w sferze ekonomicznej, wypływające z faktu wiary w jego skuteczność. Jednakże jeśli go przyjąć, zakłada się równocześnie, iż system wynika i jest oparty na argumentach irracjonalnych, z kolei jego krytycy i oponenci odwołują się do rozumu i w pełni rzeczowych argumentów.

Drugi z argumentów, tj. uzasadnienie kapitalizmu tradycją, pozostaje tylko obstawaniem za statusem quo, bez względu na to czy jest on dobry czy zły. Kryterium rozstrzygające stanowi wiek koncepcji - to, co stare musi być lepsze i właściwsze od nowych rozwiązań. Kryterium to nie może być pożądanym i decydującym miernikiem wartości ustroju gospodarczego. Rand zwraca uwagę, że idąc tym tokiem rozumowania, kapitalizm staje się obrońcą stagnacji, a inne koncepcje takie jak: kolektywizm, socjalizm, stają się realizatorem idei postępu.

Argument, biorący swe źródło w ludzkiej ułomności, odnosi się do pojęcia odpowiedzialności. Człowiek omylny, charakteryzujący się skłonnością do złego, nie może władać innymi ludźmi. Pesymistyczna antropologia nie dopuszcza zatem dyktatury, a co za tym idzie jednostka niedoskonała najpełniej rozwija się w wolnym społeczeństwie, gdzie nikt nie ponosi odpowiedzialności za jej działania.

Rand zauważa tym samym, że kapitalizm stanowi ideał, który ciągle nie został w pełni zargumentowany. Brak koherentnego wykazania racji kapitalizmu, pozwolił na wypaczenie jego założeń i obarczanie go winami innych, w pełni realizowanych koncepcji państwa. Filozofka zwraca uwagę, na fakt nierealizowania kapitalizmu w czystej formie w żadnym systemie społecznym ${ }^{32}$. Aplikując jedynie część jego założeń lub pokrewne formy, dochodzi bowiem do tworzenia porządku, który nie jest w stanie działać w sposób pożądany. Tym samym, ocena systemu daje negatywne spojrzenie na kapitalizm.

31 A. Rand, Unicestwianie kapitalizmu, w: eadem, Kapitalizm. Nieznany..., op. cit., s. ss. 296-299.

32 A. Rand, Amerykańska prześladowana..., op. cit., s. 76. 
Omawiając jednakże wizję państwa Rand, kluczowe jest przyjrzenie się definicji pojęcia kapitalizmu, które stworzyła myślicielka. Kapitalizm to nie tylko system gospodarczo-ekonomiczny, ale także obszar w którym realizowana jest pożądana i jedyna słuszna wizja jednostki w sferze etycznej.

Przede wszystkim kapitalizm, pomyślany jako urzeczywistnienie założenia laissez faire, winien zostać poznany jako zbiór zasad i system posiadający własną, unikalną naturę i historię oraz fundament doniosłej (patrząc na skutki) moralności ${ }^{33}$. W sferze etycznej kapitalizm jest system pozwalającym na realizację ludzkiego dorobku i atrybutów takich jak wiedza, myślenie i racjonalne działanie. Umożliwienie tego dokonuje się poprzez spełnienie podstawowego wymogu stawianego przed systemem instytucjonalnym - gwarancji wolności. Kapitalizm zatem chroni związek między przetrwaniem człowieka a jego użyciem rozumu.

Rozważając kapitalizm, Rand doszukała się argumentów, które jej zdaniem całkowicie go uzasadniają. Stanowią je cztery fundamenty: metafizyczny - kapitalizm spełnia wymogi natury ludzkiej i umożliwia przetrwanie jednostki, epistemologiczny - ma swe źródło w rozumie, etyczny - gwarantuje prawa człowieka oraz polityczny - urzeczywistnia ideę wolności ${ }^{34}$. Tak skonstruowana baza pozwala uznać kapitalizm za jedyny słuszny system funkcjonowania jednostki w wymiarze społecznym, politycznym, ekonomicznym i gospodarczym.

Nie można pominąć faktu, że budując teorię kapitalizmu, Rand wskazuje także na pojęcie dobra. Zdaniem autorki The Romantic Manifesto, dobro jest w sposób nierozerwalny związane z systemem ekonomiczno-społecznym. Wyróżnia ona trzy teorie dobra, które także przyczyniają się do uznania słuszności i wyższości kapitalizmu ponad inne koncepcje $^{35}$. Teorie te to:

1. teoria immanentna zakładająca, że dobro istnieje samo dla siebie i jest rozłączne z pojęciem beneficjenta ${ }^{36}$. Dobro pozostaje zatem osadzone w rzeczywistości niezależnie od ludzkiej świadomości.

\footnotetext{
33 A. Rand, Wprowadzenie..., op. cit., ss. 9-10.

34 A. Rand, Czym jest..., op. cit., s. 27.

${ }^{35}$ Ibidem, s. 30-33.

${ }^{36}$ Beneficjent jest typowym pojęciem dla Rand, które odnosi ona do rozumienia dobra i egoizmu. Jej zdaniem każdy efekt pracy człowieka powinien dawać korzyści wytwórcy i być z nim nierozerwalnie związany, w przeciwieństwie do koncepcji, zakładających wytwarzanie na rzecz lub dla innych. Cf., A. Rand, Wstęp..., op. cit.
} 
2. teoria subiektywistyczna twierdząca, że dobro nie posiada związku z realnymi faktami, lecz jest efektem uczuć, czy pragnień. Dobro jest osadzone w ludzkiej świadomości niezależnie od otaczającej nas rzeczywistości.

3. teoria obiektywna uznająca, że dobro nie jest atrybutem rzeczy samych w sobie ani stanów emocjonalnych. Stanowi natomiast oceną rzeczywistych faktów, dokonywaną przez ludzką świadomość. Jest aspektem rzeczywistości w relacji do człowieka, musi zostać przez niego odkryte. Rand wiąże zatem dobro z ludzkim rozumem oraz nie oddziela go od pojęcia beneficjenta.

Wykazując bezzasadność pierwszych dwóch teorii, myślicielka zakłada konieczność realizacji obiektywnej teorii dobra, która jest obecna i możliwa tylko w koncepcji kapitalistycznego państwa i tylko w nim może zostać urzeczywistniona w postaci wolnego rynku. To na wolnym rynku dochodzi bowiem do rozpoznania poszczególnych dóbr i ich wartości w określonym kontekście, w odniesieniu do faktów, do empirii i racjonalnych przesłanek. Wolny rynek z kolei uznawany jest nie za twór, fakt dany z góry, lecz traktowany jest jako ciągły proces odkrywania i oceny. Pozwala na zagwarantowanie rozwoju poprzez ciągłą mobilizację najbardziej utalentowanych i wykazujących się przedsiębiorczością jednostek. Te z kolei dążąc do własnego sukcesu i efektywności wpływają pobudzająco na resztę społeczeństwa ${ }^{37}$.

Idąc tym tokiem rozumowania, dochodzi się do wniosku, że kapitalizm jest jedynym systemem, pozwalającym na pełną realizację wolności jednostki i urzeczywistnienie etyki egoizmu, proponowanej przez myślicielkę i definiowanej jako cnotę ochrony własnego interesu. Sama Rand pisze: Jedyne prawdziwe uzasadnienie moralne kapitalizmu stanowi fakt, iż jest jedynym ustrojem zgodnym z natura ludzka, gdyż chroni przetrwanie człowieka jako człowieka, a jego naczelna zasada jest sprawiedliwośc ${ }^{38}$. Pozwala bowiem na ochronę podstawowych praw oraz realizowanie wolności politycznej, czyli nieskrępowanego dążenia do realizacji celów bez interwencji państwa w formie regulacji prawnych, ograniczających możliwości działania. Filozofka zauważa, że tylko wolność pozwala na rozwój oraz narodową produktywność i pomyślność ${ }^{39}$. Co więcej, zasada wymiany jest jedyna racjonalnq zasadą etyczna w sferze stosunków międzyludzkich, osobistych i społecznych, prywatnych

\footnotetext{
37 Podobne spostrzeżenia dostrzec można u Friedricha Augusta von Hayeka. Cf., F. A. von Hayek, Konstytucja wolności, tłum. J. Stawiński, Warszawa 2006.

38 A. Rand, Czym jest kapitalizm, w: eadem, Kapitalizm. Nieznany ideał, tłum. J. Łoziński, Poznań 2013, s. 28.

39 A. Rand, Tylko nie przeszkadzajcie!, w: eadem, Kapitalizm. Nieznany ideał, tłum. J. Łoziński, Poznań 2013, s. 229.
} 
i publicznych, duchowych i materialnych. Jest to bowiem zasada sprawiedliwości ${ }^{40}$. Wynika $\mathrm{z}$ tego, że reguła panująca na poziomie relacji międzyludzkich, ma swoje odbicie w porządku instytucjonalnym - kapitalizm jako idea promująca dobrowolną wymianę wiedzy i produktów (handel), umożliwia realizowanie nakazu moralnego, mającego źródło w Randowskiej etyce.

Patrząc w sposób całościowy na zaprezentowane zagadnienia nie sposób nie zauważyć, że w swych przemyśleniach Rand zwraca uwagę nie tylko na gospodarkę, jej organizację, funkcję i rolę rządu w państwie, lecz przede wszystkim na poszukiwanie systemu, pozwalającego jednostce jak najpełniej realizować wybrane wartości i cele, czyli systemu nie blokującego ambicji. Co istotne, autorka Philosophy: Who needs It, nie promuje ideału państwa minimum, co często jest promowane przez libertarian. Twierdzi wręcz, że im wyższy poziom cywilizacyjny, tym większa odpowiedzialność ciąży na państwie w postaci obrony i kontroli praw jednostki. Nie można jednak zapominać, że prawa te to przede wszystkim prawo do życia i własności. Co więcej, myślicielka wyznacza konkretne funkcje dla państwa i w pełni je argumentuje. Jej namysł chociaż bierze się z założenia o niedoskonałości ludzkiej, nie bazuje na powoływaniu władzy instytucjonalnej w celu ochrony ludzi przed sobą w sensie fizycznym, lecz w celu ochrony ich interesu, który może być bardzo szeroko rozumiany. Państwo winno być zorganizowane w ramach kapitalizmu, czyli ustroju posiadającego nie tylko wymiar praktyczny, ale także moralny ${ }^{41}$.

\section{Bibliografia}

Encyklopedia białych plam, t. XV, red. A. Winiarczyk, Radom 2005.

Libertarianizm: teoria, praktyka, interpretacje, red. W. Bulira, W. Gogłoza, Lublin 2010.

Oblicza anarchizmu i libertarianizmu w filozofii i polityce, red. J. Michalczenia, A. Sobiela, Olsztyn 2012.

Oblicza wolności: od klasycznego liberalizmu do libertarianizmu, red. T. Słupik, S. Górka, G. Szewczyk, Katowice 2012.

F. A. von Hayek, Konstytucja wolności, tłum. J. Stawiński, Warszawa 2006.

Juruś D., W poszukiwaniu podstaw libertarianizmu: w perspektywie Rothbardowskiej koncepcji własności, Kraków 2012.

\footnotetext{
40 A. Rand, Etyka absolutna..., op. cit., s. 35.

41 Cf., A. Rand, Wprowadzenie, w: eadem, Kapitalizm. Nieznany..., op. cit. lub Cf., A. Rand, Atlas zbuntowany, tłum. I. Michałowska, Poznań 2008.
} 


\section{A R T Y K U Ł Y}

Krauz-Mozer B., Szostak W., Teorie polityki: założenia metodologiczne, Warszawa 2005.

Legutko R., Leseferyzm racjonalistyczny. Ludwig von Mises i libertarianie, w: idem, Spory o kapitalizm, Kraków 1994.

Miklaszewska J., Libertariańskie koncepcje wolności i własności, Kraków 1994.

Modrzejewska M., Libertariańskie koncepcje jednostki i państwa we współczesnej amerykańskiej myśli politycznej, Kraków 2010.

Rand A., Atlas zbuntowany, tłum. I. Michałowska, Poznań 2008.

Rand A., Cnota egoizmu, tłum. na podst. wyd. Oficyny Liberałów (Warszawa 1987) i J. Łoziński, Poznań 2000.

Rand A., Kapitalizm: Nieznany ideał, tłum. J. Łoziński, Poznań 2013.

Sepczyńska D., Libertarianizm: mało znane dzieje pojęcia zakończone próbą definicji, Olsztyn 2013.

Teluk T., Koncepcje państwa we współczesnym libertarianizmie, Warszawa 2006. 